\title{
How Minority Students Experience College
}

Edited by Lemuel Watson, Melvin Terrell, Doris Wright, Fred Bonner, Michael Cuyjet, James Gold, and Dawn Person

Sterling, Virginia: Stylus Publishing, 2002, 160 pages

Reviewed by Charla T. Williams

University of Alabama

Higher education professionals can forget or ignore the needs of minority students. Specific, unique needs of multicultural students can get lost in the shuffle of everyday procedures on any given campus. How Minority Students Experience College provides and insightful, compelling look at the daily struggles that multiethnic students can face everyday on campus. The authors point out that the book does not serve as a guide to achieve multiculturalism or pluralism, but provides information on how minority students feel about the predominantly white institutions they attend. 
The first half of Minority Students presents the book's purpose and research methods. Chapter One defines multiculturalism, which gives the reader a sense of the authors' purpose. The authors document others definitions of multiculturalism, and sum up the chapter with their own offering. They define multiculturalism as a "state of being in which humans feel comfortable in their communication with people from any culture, in any situation, because they desire to learn about others and are empathic in their quest" (p. 10). Other definitions of multiculturalism focus on mutual respect and the acknowledgement of other cultures, while Watson and associates include the desire to learn about others. Multiculturalism serves as the reason for the work and research put into the book. Minority Students would not be of value if all predominantly white institutions achieved multiculturalism.

Chapters two and three discuss the colleges researched and research methods. After researching 289 institutions the research team chose seven small (3,350 or less students) liberal arts colleges, although the authors do not reveal the names and demographics of the colleges. Qualitative research methods were used, and the research team interviewed minority students from each college individually and as a group. Students spoke freely concerning their places as minority students in the predominantly white institutions they attend. The research team did not alter the recorded student comments or push students to reply in a particular way.

The second half of the book provided feedback from those students interviewed, and implications. Chapters four, five, and six included student comments concerning admissions and recruitment, class interaction, and club involvement, while Chapter Seven provided a discussion of findings and implications. Watson and associates organized headings and subheadings according to student comments. This allowed the reader to associate posed questions with student replies.

For the most part student comments contained similarities. The documented comments followed a common theme, which created a better understanding and meaning of the book. Most students felt few programs and college personnel helped them with the daily struggles of being a minority student, and believed the programs designed especially for them isolated them more than helped them. The authors adequately display both sides of minority students' comments. For example, students not involved in campus organizations felt a heightened sense of negativity toward the college compared to heavily involved students.

Chapter Seven mentioned the biased nature of student comments. However, the authors did not elaborate on this subject. The mention of bias left questions of the accuracy of the findings, and their reasoning for not conducting less biased research. The research team surveyed institutions of only 3350 students or less. Therefore, it is doubtful that the findings compare to larger colleges and universities.

The detail of research methods left little time for results and implications. In my opinion, the authors overextended the descriptions of research methods. For this reason, the reader loses interest in the first three chapters. However, the book eventually recovered with the explicit (and interesting) student opinions.

How Minority Students Experience College brought about new meaning concerning the treatment of minority students in a predominantly white institution. Prior to reading 
the book I had not explored the idea that the treatment of minority students is a daily task to be performed and evaluated. The book is recommended for all higher education professionals to ponder over the findings and discover answers to institutional questions. 